\title{
DETERMINAN MATRIKS SIRKULAN DENGAN METODE KONDENSASI DODGSON
}

\author{
M. R. Fahlevi ${ }^{1}$ \\ ${ }^{1}$ Institut Agama Islam Negeri Syaikh Abdurrahman Siddik Bangka Belitung \\ ${ }^{1}$ mahfudzrezafahlevi@iainsasbabel.ac.id
}

\begin{abstract}
One of the important topics in mathematics is matrix theory. There are various types of matrix, one of which is a circulant matrix. Circulant matrix generally fulfill the same operating axioms as square matrix, except that there are some specific properties for the circulant matrix. Every square matrix has a determinant. The concept of determinants is very useful in the development of mathematics and across disciplines. One method of determining the determinant is condensation. The condensation method is classified as a method that is not widely known. The condensation matrix method in determining the determinant was proposed by several scientists, one of which was Charles Lutwidge Dodgson with the Dodgson condensation method. This paper will discuss the Dodgson condensation method in determining the determinant of the circulant matrix. The result of the condensation of the matrix will affect the size of the original matrix as well as new matrix entries. Changes in the circulant matrix after Dodgson's conduction load the Toeplitz matrix, in certain cases, the determinant of the circulant matrix can also be determined by simple mental computation.
\end{abstract}

Keywords : : Determinant, Dodgson Condensation, Circulant Matrix

\section{ABSTRAK}

Salah satu bahasan penting dalam ilmu matematika adalah teori matriks. Terdapat berbagai jenis matriks, salah satunya adalah matriks sirkulan. Matriks sirkulan umumnya memenuhi aksioma operasi yang sama dengan matriks persegi, hanya saja ada beberapa kekhususan sifat bagi matriks sirkulan. Setiap matriks persegi memiliki determinan. Konsep determinan sangat berguna dalam pengembangan ilmu matematika maupun lintas ilmu. Salah satu metode dalam menentukan determinan adalah dengan kondensasi. Metode kondensasi (penyusutan) tergolong sebagai metode yang belum dikenal secara luas. Metode kondensasi matriks dalam menentukan determinan dikemukakan oleh beberapa ilmuwan, salah satunya adalah Charles Lutwidge Dodgson dengan metode kondensasi Dodgson. Dalam paper ini akan dibahas metode kondesasi Dodgson dalam menentukan determinan matriks sirkulan. Hasil kondensasi matriks akan mempengaruhi ukuran matriks awal (penyusutan) dan juga entri-entri matriks yang baru. Perubahan matriks sirkulan setelah dilakukan kondesasi Dodgson memuat matriks matriks Toeplitz, pada kasus tertentu, determinan matriks sirkulan juga dapat ditentukan dengan perhitungan mental sederhana.

Kata kunci : Determinan, Kondensasi Dodgson, Matriks Sirkulan 


\section{PENDAHULUAN}

\subsection{Latar Belakang}

Matriks adalah jajaran berbentuk persegi panjang yang diatur berdasarkan baris dan kolom yang diletakkan antara dua tanda kurung (Fitriyani dkk, 2018). Terdapat berbagai jenis matriks, salah satunya adalah matriks sirkulan. Matriks sirkulan secara umum memenuhi aksioma operasi yang sama dengan matriks persegi, hanya saja matriks sirkulan mempunyai sifat khusus, yakni hasil perkaliannya yang komutatif dan sifat ketertutupan yang terdefinisi dengan baik (Fahlevi, 2020). Matriks sirkulan adalah matriks dengan entri pada setiap baris identik dengan yang ada pada baris sebelumnya, namun dipindahkan satu posisi ke kanan untuk mengitarinya. Keseluruhan entri pada matriks sirkulan ditentukan oleh entri pada baris pertama (Davis, 1979). Ada beberapa jenis matriks sirkulan yaitu matriks semi sirkulan, matriks reverse sirkulan (left sirkulan), dan matriks $k$-sirkulan. Pembahasan dalam paper ini akan berfokus pada keterkaitan determinan matriks sirkulan dan hasil matriks kondensasi Dodgsonnya.

Salah satu pembahasan penting dalam teori matriks adalah menentukan determinan matriks. Determinan mempunyai peranan penting dalam menyelesaikan beberapa persoalan dalam matriks dan banyak dipergunakan dalam ilmu matematika maupun ilmu terapannya (Rahma dkk, 2019). Determinan matriks memiliki sejarah yang panjang, bahkan lebih panjang daripada ilmu matriks itu sendiri (Goldberg, 1991). Konsep determinan sangat berguna dalam pengembangan ilmu Matematika serta aplikasi pada lintas ilmu. Dalam menentukan nilai determinan ada beberapa metode yang pernah digunakan yakni metode Sarrus, ekspansi kofaktor, reduksi baris, metode Gbemi's, metode Jacobi dan metode kondensasi. Metode kondensasi atau disebut metode penyusutan tergolong sebagai metode yang belum semua orang mengenalnya secara luas. Metode kondensasi matriks dalam menentukan determinan dikemukakan oleh beberapa ilmuwan, yakni Felice Chio dengan metode kondesasi Chio pada tahun 1853, Charles Lutwidge Dodgson/Lewis Caroll dengan metode kondensasi Dodgson pada tahun 1867, dan oleh Armend Salihu dengan metode kondesasi Salihu pada tahun 2012.

\subsection{Tujuan Penelitian}

Paper ini bertujuan untuk membahas metode kondesasi Dodgson dalam menentukan determinan matriks sirkulan. Hasil kondensasi tiap matriks persegi akan mempengaruhi ukuran matriks awal (penyusutan) dan juga entri-entri matriks yang baru, begitu pula dengan matriks sirkulan. Perubahan matriks sirkulan atas metode kondensasi Dodgson akan memuat matriks matriks Toeplitz. Pada kasus tertentu, determinan matriks sirkulan juga dapat ditentukan dengan perhitungan mental sederhana. 


\section{METODE PENELITIAN}

Metode penelitian dalam paper ini berupa kajian studi literatur dan pengumpulan referensi yang relevan sebagi sumber utama. Pemahaman definisi dan terminologi tentang matriks sirkulan dan penentuan determinan dengan metode kondensasi Dodgson. Mengamati perubahan matriks sirkulan yang telah menyusut (terjadi kondensasi) dengan metode kondensasi Dodgson yang kemudian akan ditentukan tentang teorema, lemma dan corollary dari hasil pengamatan tersebut.

\section{HASIL DAN PEMBAHASAN}

Matriks sirkulan merupakan salah satu jenis matriks Toeplitz yang khusus (Gray, 2006). Dalam paper ini, matriks Toeplitz akan dibahas adalah matriks berbentuk persegi karena akan saling berkaitan dengan matriks sirkulan yang merupakan matriks persegi. Terminologi matriks Toeplitz dan matriks sirkulan yang akan diperkenalkan adalah sebagai berikut:

Definisi 1: Suatu matriks $n \times n$ merupakan matriks Toeplitz, $T_{n}=\left[t_{k, j} ; k, j=0,1, \cdots, n-1\right]$ dengan $t_{k, j}=t_{k-j}$. Matriks dengan bentuk:

$$
T_{n}=\left(\begin{array}{ccccc}
t_{0} & t_{-1} & t_{-2} & \cdots & t_{-(n-1)} \\
t_{1} & t_{0} & t_{-1} & \cdots & t_{-(n-2)} \\
t_{2} & t_{1} & t_{0} & \cdots & t_{-(n-3)} \\
\vdots & \vdots & \vdots & \ddots & \vdots \\
t_{n-1} & t_{n-2} & t_{n-3} & \cdots & t_{0}
\end{array}\right)
$$

Definisi 2: Matriks sirkulan merupakan matriks kasus khusus dari matriks Toeplitz, yakni matriks yang mengalami perpindahan secara siklik ke kanan untuk tiap baris kedua dan berikutnya sehingga $t_{k}=t_{-(n-k)}=t_{k-n}$ untuk $k=1,2, \cdots, n-1$. Matriks dengan bentuk:

$$
C_{n}=\left(\begin{array}{ccccc}
t_{0} & t_{-1} & t_{-2} & \cdots & t_{-(n-1)} \\
t_{-(n-1)} & t_{0} & t_{-1} & \cdots & t_{-(n-2)} \\
t_{-(n-2)} & t_{-(n-1)} & t_{0} & \cdots & t_{-(n-3)} \\
\vdots & \vdots & \vdots & \ddots & \vdots \\
t_{-1} & t_{-2} & t_{-3} & \cdots & t_{0}
\end{array}\right)
$$

matriks sirkulan $C_{n}$, cukup dituliskan dengan $C_{n}=\left(t_{0}, t_{-1}, t_{-2}, \cdots, t_{-(n-1)}\right)$.

Setiap matriks persegi memiliki determinan. Terdapat berbagai teknik dalam menentukan nilai determinan, salah satunya adalah dengan meotode kondensasi Dodgson. Determinan dengan menggunakan metode kondensasi Dodgson (Dodgson, 1867) harus memenuhi aturan yang ditetapkan. Suatu matriks berukuran $n \times n$ dapat ditentukan determinannya dengan cara berikut:

1. Atur matriks yang diberikan sehingga tidak ada entri interior yang bersesuaian adalah nol (cipher occurs). Pengaturan ini dapat dilakukan dengan mentransposisi baris atau kolom.

2. Hitung determinan setiap minor yang berdekatan. Nilai-nilai akan membentuk matriks hasil kondensasi (matriks kedua) yang terdiri atas $(n-1)$ baris dan $(n-1)$ kolom.

3. Lakukan kondesasi lagi pada matriks kedua dengan cara yang sama, kemudian membagi tiap entri yang bersesuaian dengan interior pada matriks sebelumnya. 
4. Ulangi proses ini hingga mendapat matriks berukuran $2 \times 2$ dan terus membaginya dengan interior pada matriks sebelumnya hingga mendapat nilai determinan.

\section{Contoh 1:}

Sebagai contoh untuk matriks berukuran $4 \times 4$ :

\begin{tabular}{|c|c|c|}
\hline matriks 1 & interior matriks 1 & kondensasi matriks 1 \\
\hline$\left(\begin{array}{cccc}-2 & -1 & -1 & -4 \\
-1 & -\mathbf{2} & -\mathbf{1} & -6 \\
-1 & \mathbf{- 1} & \mathbf{2} & 4 \\
2 & 1 & -3 & -8\end{array}\right)$ & $\left|\begin{array}{cc}-2 & -1 \\
-1 & 2\end{array}\right|$ & 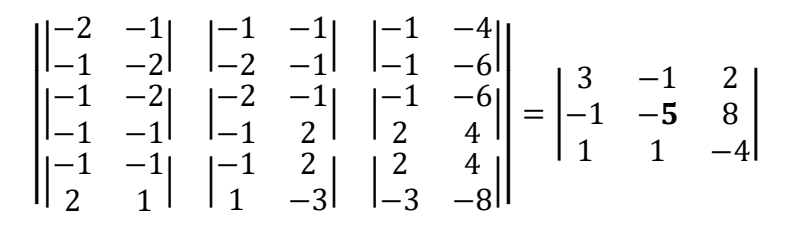 \\
\hline matriks 2 & interior matriks 2 & kondensasi matriks 2 \\
\hline$\left|\begin{array}{ccc}3 & -1 & 2 \\
-1 & -5 & 8 \\
1 & 1 & -4\end{array}\right|$ & $\begin{array}{l}\text {-5 } \\
\text { *berupa } \\
\text { bilangan }\end{array}$ & 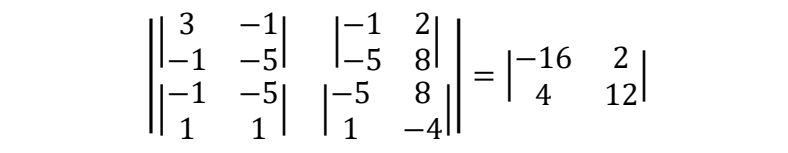 \\
\hline $\begin{array}{l}\text { karena kondensasi } \mathrm{m} \\
\text { matriks } 2 \text { dibagi denga }\end{array}$ & $\begin{array}{l}\text { ks } 2 \text { bersesuaian } \\
\text { entri yang bersesuai } \\
\qquad \begin{array}{c}\frac{-16}{-2} \\
\frac{4}{-1}\end{array}\end{array}$ & $\begin{array}{l}\text { lengan interior matriks } 1 \text {, maka entri pada kondensasi } \\
\text { dengan interior matriks } 1 \text {, yaitu: } \\
\frac{2}{-1}|=| \begin{array}{cc}8 & -2 \\
-4 & 6\end{array} \mid\end{array}$ \\
\hline matriks 3 & $\begin{array}{l}\text { matriks }(2 \times 2) \text {, } \\
\text { cukup cari } \\
\text { determinan }\end{array}$ & $\begin{array}{l}\text { bagi determinan pada hasil matriks yang telah } \\
\text { berukuran }(2 \times 2) \text { dengan interior bilangan, maka } \\
\text { didapat determinan matriks awal. }\end{array}$ \\
\hline$\left(\begin{array}{cc}8 & -2 \\
-4 & 6\end{array}\right)$ & $\left|\begin{array}{cc}8 & -2 \\
-4 & 6\end{array}\right|=40$ & $\frac{40}{-5}=-8$ \\
\hline
\end{tabular}

untuk kasus tertentu, perlu dilakukan pengaturan agar interior matriks tidak memiliki cipher occurs yang berakibat pada pembagian dengan bilangan nol. Berikut ini contoh terjadinya cipher occurs pada kondensasi ketiga (contoh matriks sebalah kiri), sehingga langkah berikutnya tidak bisa dilanjutkan. Determinan tetap dapat ditentukan dengan kondensasi, namun perlu mengatur ulang matriks (contoh sebelah kanan), yakni menukar baris pertama ke baris paling bawah sehingga tidak terjadi cipher occurs. 


\section{Contoh 2}

Kondensasi dengan cipher occurs

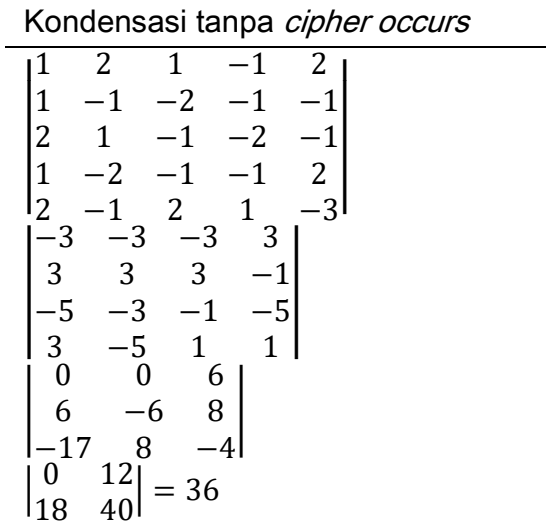

\subsection{Determinan Matriks Sirkulan Dengan Metode Kondensasi Dodgson}

Remark contoh 1, perhatikan bahwa determinan matriks awal yakni -8 tidak dapat ditentukan secara langsung dengan kondensasi matriks 1 . Hasil kondensasi matriks 1 yaitu $\left(\begin{array}{ccc}3 & -1 & 2 \\ -1 & -5 & 8 \\ 1 & 1 & 4\end{array}\right)$ memiliki nilai determinan $\left|\begin{array}{ccc}3 & -1 & 2 \\ -1 & -5 & 8 \\ 1 & 1 & 4\end{array}\right|=-88$. Hal ini menunjukkan bahwa determinan matriks 1 kondensasi Dodgson secara umum tidak berkaitan langsung dengan determinan matriks awal. namun untuk kasus tertentu pada matriks sirkulan, matriks kondensasi 1 dapat digunakan untuk menentukan determinan matriks awal. Berikut ini teorema tentang kondensasi Dodgson yang diaplikasikan pada matriks sirkulan.

Teorema 1: Entri matriks kondensasi Dodgson pada matriks sirkulan berukuran $n$ memiliki $x$ entri berbeda sedemikian sehingga $x \leq n$.

\section{Bukti:}

Diberikan matriks sirkulan $A_{n}=\left(a_{0}, a_{1}, a_{2}, \cdots, a_{n-3}, a_{n-2}, a_{n-1}\right)$, yakni:

$$
A_{n}=\left(\begin{array}{ccccccc}
a_{0} & a_{1} & a_{2} & \cdots & a_{n-3} & a_{n-2} & a_{n-1} \\
a_{n-1} & a_{0} & a_{1} & \cdots & a_{n-4} & a_{n-3} & a_{n-2} \\
a_{n-2} & a_{n-1} & a_{0} & \cdots & a_{n-5} & a_{n-4} & a_{n-3} \\
\vdots & \vdots & \vdots & \ddots & \vdots & \vdots & \vdots \\
a_{3} & a_{4} & a_{5} & \cdots & a_{0} & a_{1} & a_{2} \\
a_{2} & a_{3} & a_{4} & \cdots & a_{n-1} & a_{0} & a_{1} \\
a_{1} & a_{2} & a_{3} & \cdots & a_{n-2} & a_{n-1} & a_{0}
\end{array}\right)
$$

sedemikian sehingga matriks kondensasi Dodgson pertama pada matriks sirkulan $C_{n}$ diatas adalah:

$$
\left|\begin{array}{ccccc}
a_{0}{ }^{2}-a_{1} \cdot a_{n-1} & a_{1}{ }^{2}-a_{0} \cdot a_{2} & \cdots & a_{n-3}{ }^{2}-a_{n-2} \cdot a_{n-4} & a_{n-2}{ }^{2}-a_{n-1} \cdot a_{n-3} \\
a_{n-1}{ }^{2}-a_{0} \cdot a_{n-1} & a_{0}{ }^{2}-a_{1} \cdot a_{n-1} & \cdots & a_{n-4}{ }^{2}-a_{n-3} \cdot a_{n-5} & a_{n-3}{ }^{2}-a_{n-2} \cdot a_{n-4} \\
\vdots & \vdots & \ddots & \vdots & \vdots \\
a_{3}{ }^{2}-a_{2} \cdot a_{4} & a_{4}{ }^{2}-a_{3} \cdot a_{5} & \cdots & a_{0}{ }^{2}-a_{1} \cdot a_{n-1} & a_{1}{ }^{2}-a_{0} \cdot a_{2} \\
a_{2}{ }^{2}-a_{1} \cdot a_{3} & a_{3}{ }^{2}-a_{2} \cdot a_{4} & \cdots & a_{n-1}{ }^{2}-a_{0} \cdot a_{n-2} & a_{0}{ }^{2}-a_{1} \cdot a_{n-1}
\end{array}\right|
$$

matriks diatas memuat entri-entri yang sama di posisi tertentu, sehingga dapat dilakukan permisalan pada hasil entri-entri diatas, yakni: 
$\theta_{0}=\left(a_{0}\right)^{2}-a_{1} \cdot a_{n-1} ; \theta_{1}=\left(a_{1}\right)^{2}-a_{0} \cdot a_{2} ; \cdots ; \theta_{n-3}=\left(a_{n-3}\right)^{2}-a_{n-2} \cdot a_{n-4}$

$\theta_{n-2}=\left(a_{n-2}\right)^{2}-a_{n-1} \cdot a_{n-3} ; \theta_{n-1}=\left(a_{n-1}\right)^{2}-a_{0} \cdot a_{n-1}$

sehingga kondensasi matriks 1 dapat dituliskan sebagai berikut:

$$
\left|\begin{array}{ccccc}
\theta_{0} & \theta_{1} & \cdots & \theta_{n-3} & \theta_{n-2} \\
\theta_{n-1} & \theta_{0} & \cdots & \theta_{n-4} & \theta_{n-3} \\
\vdots & \vdots & \ddots & \vdots & \vdots \\
\theta_{3} & \theta_{4} & \cdots & \theta_{0} & \theta_{1} \\
\theta_{2} & \theta_{3} & \cdots & \theta_{n-1} & \theta_{0}
\end{array}\right|
$$

pandang bahwa bentuk matriks pada persamaan terakhir merupakan matriks yang memiliki entri dari $\theta_{0}$ hingga $\theta_{n-2}$ yapada baris pertama, kemudian terdapat entri berbeda pada baris kedua yaitu $\theta_{n-1}$, sehingga banyak entri pada matriks pertama kondensasi adalah sebanyak $n$ entri yang artinya banyak entri berbeda maksimal adalah $n$.

Salah satu sifat khusus pada matriks sirkulan adalah sifat ketertutupan yang terdefinisi dengan baik pada operasi penjumlahan dan perkalian, namun hasil kondensasi Dodgson pada matriks sirkulan bukanlah suatu matriks sirkulan, namun memenuhi bentuk matriks Toeplitz. Corollary dari teorema 1 dijelaskan sebagai berikut:

Corollarry 1: Matriks kondensasi Dodgson pertama pada matriks sirkulan memenuhi bentuk matriks Toeplitz

Bukti:

Remark teorema 1. Pandang matriks kondensasi 1 atas matriks sirkulan adalah sebagai berikut:

$$
\left|\begin{array}{ccccc}
\theta_{0} & \theta_{1} & \cdots & \theta_{n-3} & \theta_{n-2} \\
\theta_{n-1} & \theta_{0} & \cdots & \theta_{n-4} & \theta_{n-3} \\
\vdots & \vdots & \ddots & \vdots & \vdots \\
\theta_{3} & \theta_{4} & \cdots & \theta_{0} & \theta_{1} \\
\theta_{2} & \theta_{3} & \cdots & \theta_{n-1} & \theta_{0}
\end{array}\right|
$$

tiap entri matriks tersebut memenuhi $\theta_{k, j}=\theta_{k-j}$ sehingga membentuk susunan matriks Toeplitz.

Determinan matriks sirkulan dengan metode kondensasi Dodgson pada kasus tertentu akan sangat erat kaitannya dengan kondensasi Dodgson matriks segitiga bawah. Lemma berikut akan sangat berguna untuk pengaplikasian determinan dengan metode kondensasi Dodgson pada matriks sirkulan. 
Lemma 1: Kondensasi matriks segitiga bawah merupakan matriks segitiga bawah

Bukti:

Diberikan matriks segitiga bawah $B_{n}$ sedemikian sehinggan proses kondensasi Dodgson adalah sebagai berikut:

$$
B_{n}=\left(\begin{array}{ccccccc}
b_{11} & 0 & 0 & \cdots & 0 & 0 & 0 \\
b_{21} & b_{22} & 0 & \cdots & 0 & 0 & 0 \\
b_{31} & b_{32} & b_{33} & \cdots & 0 & 0 & 0 \\
\vdots & \vdots & \vdots & \ddots & \vdots & \vdots & \vdots \\
b_{n-2,1} & b_{n-2,2} & b_{n-2,3} & \cdots & b_{n-2, n-2} & 0 & 0 \\
b_{n-1,1} & b_{n-1,2} & b_{n-1,3} & \cdots & b_{n-1, n-2} & b_{n-1, n-1} & 0 \\
b_{n 1} & b_{n 2} & b_{n 3} & \cdots & b_{n, n-2} & b_{n, n-1} & b_{n n}
\end{array}\right)
$$

kondensasi matriks 1 pada matriks $B_{n}$ diatas adalah:

$$
\left|\begin{array}{cccc}
b_{11} b_{22} & 0 & \cdots & 0 \\
b_{21} b_{32}-b_{22} b_{31} & b_{22} b_{33} & \cdots & 0 \\
\vdots & \vdots & \ddots & \vdots \\
b_{n-2,1} b_{n-1,2}-b_{n-2,2} b_{n-1,1} & b_{n-2,2} b_{n-1,3}-b_{n-2,3} b_{n-1,2} & \cdots & 0 \\
b_{n-1,1} b_{n 2}-b_{n-1,2} b_{n 1} & b_{n-1,2} b_{n 3}-b_{n-1,3} b_{n 2} & 0 & 0
\end{array}\right|
$$

tiap entri matriks tersebut memenuhi definisi matriks segitiga bawah.

\subsection{Determinan Matriks Sirkulan Bentuk Khusus Dengan Metode Kondensasi Dodgson}

Berikutnya, akan dibuktikan teorema tentang kondensasi matriks sirkulan pada bentuk khusus yang memiliki entri berkelipatan.

Teorema 2: Kondensasi matriks pertama dari matriks sirkulan $A_{n}=$ $\left(a_{0}, a_{1}, a_{2}, \cdots, a_{n-1}\right)$ sedemikian sehingga $a_{i}=a \cdot b^{i}$ dengan $a$ dan $b$ suatu konstanta, merupakan matriks bidiagonal bawah (bidiagonal lower matrix)

Bukti:

Diberikan matriks sirkulan $A_{n}=\left(a, a b, a b^{2}, \cdots, a b^{n-3}, a b^{n-2}, a b^{n-1}\right)$, yakni:

$$
A_{n}=\left(\begin{array}{ccccccc}
a & a b & a b^{2} & \cdots & a b^{n-3} & a b^{n-2} & a b^{n-1} \\
a b^{n-1} & a & a b & \cdots & a b^{n-4} & a b^{n-3} & a b^{n-2} \\
a b^{n-2} & a b^{n-1} & a & \cdots & a b^{n-5} & a b^{n-4} & a b^{n-3} \\
\vdots & \vdots & \vdots & \ddots & \vdots & \vdots & \vdots \\
a b^{3} & a k^{4} & a b^{5} & \cdots & a & a b & a b^{2} \\
a b^{2} & a b^{3} & a b^{4} & \cdots & a b^{n-1} & a & a b \\
a b & a b^{2} & a b^{3} & \cdots & a b^{n-2} & a b^{n-1} & a
\end{array}\right)
$$

sedemikian sehingga matriks kondensasi Dodgson pertama adalah sebagai berikut:

$$
\left|\begin{array}{ccccc}
a^{2}-a b \cdot a b^{n-1} & 0 & \cdots & 0 & 0 \\
\left(a b^{n-1}\right)^{2}-a \cdot a b^{n-2} & a^{2}-a b \cdot a b^{n-1} & \cdots & 0 & 0 \\
\vdots & \vdots & \ddots & \vdots & \vdots \\
0 & 0 & \cdots & a^{2}-a b \cdot a b^{n-1} & 0 \\
0 & 0 & \cdots & \left(a b^{n-1}\right)^{2}-a \cdot a b^{n-2} & a^{2}-a b \cdot a b^{n-1}
\end{array}\right|
$$


tiap entri matriks tersebut memenuhi definisi untuk membentuk susunan matriks bidiagonal bawah (bidiagonal lower matrix).

Pada teorema 2 diperlihatkan bahwa kondensasi matriks pertama matriks sirkulan dengan bentuk khusus adalah matriks bidiagonal bawah. Matriks bidiagonal bawah merupakan salah satu contoh matriks segitiga bawah. Berdasarkan lemma 1, kondensasi matriks segitiga bawah juga merupakan segitiga bawah sehingga dapat dibentuk suatu rumus baku untuk menentukan determinan matriks sirkulan bentuk khusus seperti dalam teorema 2 .

Teorema 3: Determinan matriks sirkulan $A_{n}=\left(a_{0}, a_{1}, a_{2}, \cdots, a_{n-1}\right)$ sedemikian sehingga $a_{i}=a \cdot b^{i}$ dengan $a$ dan $b$ suatu konstanta adalah: $\left|A_{n}\right|=a\left(a-a b^{n}\right)^{n-1}$

Bukti:

Pembuktian pada teorema 3 akan menggunakan metode induksi dengan tata cara yang bersesuaian dengan (Siregar, 2014). Andaikan $A_{n}$ adalah matriks sirkulan $A_{n}=$ $\left(a_{0}, a_{1}, a_{2}, \cdots, a_{n-1}\right)$ sedemikian sehingga $a_{i}=a \cdot b^{i}$ dengan $a$ dan $b$ suatu konstanta dengan ordo $n \geq 2$ yakni $\{2,3,4,5, \cdots, n\}$.

Langkah pertama. Diperlihatkan bahwa $\left|A_{2}\right|,\left|A_{3}\right|,\left|A_{4}\right|, \cdots,\left|A_{n}\right|$ memiliki pola untuk setiap $n \geq 2$.

1. Andaikan matriks $A_{2}=\left(a_{0}, a_{1}\right)$ sehingga diperoleh:

$$
\left|A_{2}\right|=\left|\begin{array}{cc}
a_{0} & a_{1} \\
a_{1} & a_{0}
\end{array}\right|=\left|\begin{array}{cc}
a & a k \\
a k & a
\end{array}\right|=a^{2}-a^{2} b^{2}=a\left(a-a b^{2}\right)
$$

2. Andaikan matriks $A_{3}=\left(a_{0}, a_{1}, a_{2}\right)$ sehingga diperoleh:

$$
\left|A_{3}\right|=\left|\begin{array}{lll}
a_{0} & a_{1} & a_{2} \\
a_{2} & a_{0} & a_{1} \\
a_{1} & a_{2} & a_{0}
\end{array}\right|=\left|\begin{array}{ccc}
a & a b & a b^{2} \\
a b^{2} & a & a b \\
a b & a b^{2} & a
\end{array}\right|
$$

interior matriks $A_{3}=a$

matriks kondensasi $\left|\begin{array}{cc}\left|\begin{array}{cc}a & a b \\ a b^{2} & a\end{array}\right| & \left|\begin{array}{cc}a b & a b^{2} \\ a & a b\end{array}\right| \\ \begin{array}{cc}a b^{2} & a \\ a b & a b^{2}\end{array} \mid & \left|\begin{array}{cc}a & a b \\ a b^{2} & a\end{array}\right|\end{array}\right|=\left|\begin{array}{cc}a^{2}-a^{2} b^{3} & 0 \\ a^{2} b^{4}-a^{2} b & a^{2}-a^{2} b^{3}\end{array}\right|$

karena hasil kondensasi matriks bersesuaian dengan interior matriks, maka entri pada kondensasi matriks dibagi dengan entri yang bersesuaian dengan interior matriks, yaitu:

$$
\left|\begin{array}{cc}
\frac{a^{2}-a^{2} b^{3}}{a} & \frac{0}{a} \\
\frac{a^{2} b^{4}-a^{2} b}{a} & \frac{a^{2}-a^{2} b^{3}}{a}
\end{array}\right|=\left|\begin{array}{cc}
a-a b^{3} & 0 \\
a b^{4}-a b & a-a b^{3}
\end{array}\right|
$$

sehingga:

$$
\left|A_{3}\right|=\left|\begin{array}{cc}
a-a b^{3} & 0 \\
a b^{4}-a b & a-a b^{3}
\end{array}\right|=\left(a-a b^{3}\right)^{2}=a\left(a-a b^{3}\right)^{2}
$$

3. Andaikan matriks $A_{4}=\left(a_{0}, a_{1}, a_{2}, a_{3}\right)$ sehingga diperoleh:

$$
\left|A_{4}\right|=\left|\begin{array}{cccc}
a_{0} & a_{1} & a_{2} & a_{3} \\
a_{3} & a_{0} & a_{1} & a_{2} \\
a_{2} & a_{3} & a_{0} & a_{1} \\
a_{1} & a_{2} & a_{3} & a_{0}
\end{array}\right|=\left|\begin{array}{cccc}
a & a b & a b^{2} & a b^{3} \\
a b^{3} & a & a b & a b^{2} \\
a b^{2} & a b^{3} & a & a b \\
a b & a b^{2} & a b^{3} & a
\end{array}\right|
$$


interior matriks $1 A_{4}=\left|\begin{array}{cc}a & a k \\ a k^{3} & a\end{array}\right|$ matriks kondensasi 1:

$$
\left|\begin{array}{cccc}
\left|\begin{array}{cc}
a & a b \\
a b^{3} & a
\end{array}\right| & \left|\begin{array}{cc}
a b & a b^{2} \\
a & a b
\end{array}\right| & \left|\begin{array}{cc}
a b^{2} & a b^{3} \\
a b & a b^{2}
\end{array}\right| \\
\left|\begin{array}{cc}
a b^{3} & a \\
a b^{2} & a b^{3}
\end{array}\right| & \left|\begin{array}{cc}
a & a b \\
a b^{3} & a
\end{array}\right| & \begin{array}{cc}
a b & a b^{2} \\
a & a b
\end{array} \mid \\
\left|\begin{array}{cc}
a b^{2} & a b^{3} \\
a b & a b^{2}
\end{array}\right| & \left|\begin{array}{cc}
a b^{3} & a \\
a b^{2} & a b^{3}
\end{array}\right| & \left|\begin{array}{cc}
a & a b \\
a b^{3} & a
\end{array}\right|
\end{array}\right|=\left|\begin{array}{ccc}
a^{2}-a^{2} b^{4} & 0 & 0 \\
a^{2} b^{6}-a^{2} b^{2} & a^{2}-a^{2} b^{4} & 0 \\
0 & a^{2} b^{6}-a^{2} b^{2} & a^{2}-a^{2} b^{4}
\end{array}\right|
$$

interior matriks $2 A_{4}=a^{2}-a^{2} b^{4}=a^{2}\left(1-b^{4}\right)$

matriks kondensasi 2:

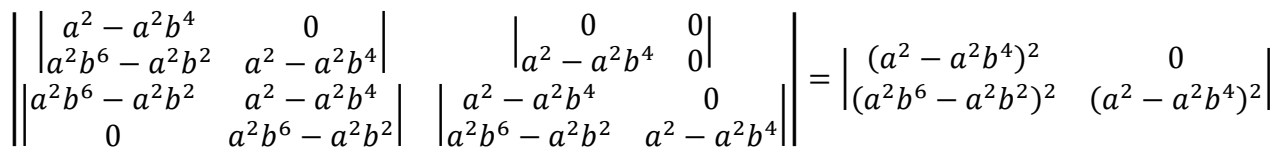

karena kondensasi matriks 2 bersesuaian dengan interior matriks 1 , maka entri pada kondensasi matriks 2 dibagi dengan entri yang bersesuaian dengan interior matriks 1 , yaitu:

$$
\left|\begin{array}{cc}
\frac{\left(a^{2}-a^{2} b^{4}\right)^{2}}{a} & \frac{0}{a b} \\
\frac{\left(a^{2} b^{6}-a^{2} b^{2}\right)^{2}}{a b^{3}} & \frac{\left(a^{2}-a^{2} b^{4}\right)^{2}}{a}
\end{array}\right|=\left|\begin{array}{cc}
a^{3}\left(1-b^{4}\right)^{2} & 0 \\
a^{3} b\left(b^{4}-1\right)^{2} & a^{3}\left(1-b^{4}\right)^{2}
\end{array}\right|=a^{6}\left(1-b^{4}\right)^{4}
$$

Hasil determinan pada persamaan terakhir bersesuaian dengan interior matriks 1 , sehingga didapat determinan matriks $A_{4}$, yaitu:

$$
\left|A_{4}\right|=\frac{a^{6}\left(1-b^{4}\right)^{4}}{a^{2}\left(1-b^{4}\right)}=a^{4}\left(1-b^{4}\right)^{3}=a\left(a-a b^{4}\right)^{3}
$$

4. dan seterusnya, untuk $\left|A_{5}\right|,\left|A_{6}\right|, \cdots,\left|A_{n}\right|$

dengan mengamati $\left|A_{2}\right|,\left|A_{3}\right|,\left|A_{4}\right|, \cdots,\left|A_{n}\right|$ diperlihatkan bahwa $\left|A_{3}\right|$ bergantung pada $\left|A_{2}\right|$, kemudian $\left|A_{4}\right|$ bergantung pada $\left|A_{3}\right|$ sehingga $\left|A_{n+1}\right|$ bergantung pada $\left|A_{n}\right|$.

Langkah kedua. Asumsikan $\left|\boldsymbol{A}_{\boldsymbol{n}}\right|=\boldsymbol{a}\left(\boldsymbol{a}-\boldsymbol{a} \boldsymbol{b}^{\boldsymbol{n}}\right)^{\boldsymbol{n}-1}$ adalah benar, untuk $n \geq 2$ sedemikian sehingga $\left|A_{n+1}\right|=a\left(a-a b^{n+1}\right)^{n}$ sehingga pola atau selisih dari $\left|A_{n}\right|$ menuju $\left|A_{n+1}\right|$ adalah:

$$
\frac{\left|A_{n+1}\right|}{\left|A_{n}\right|}=\frac{a\left(a-a b^{n+1}\right)^{n}}{a\left(a-a b^{n}\right)^{n-1}}=\frac{a\left(1-b^{n+1}\right)^{n}}{\left(1-b^{n}\right)^{n-1}}
$$

jadi untuk $n=k,\left|A_{k}\right|=a\left(a-a b^{k}\right)^{k-1}$ sedemikian hingga untuk $n=k+1$ diperoleh:

$$
\begin{aligned}
\left|A_{n+1}\right| & =A_{n} \cdot\left(\frac{a\left(1-b^{n+1}\right)^{n}}{\left(1-b^{n}\right)^{n-1}}\right) \\
& =a\left(a-a b^{n}\right)^{n-1} \cdot\left(\frac{a\left(1-b^{n+1}\right)^{n}}{\left(1-b^{n}\right)^{n-1}}\right) \\
& =a\left(a^{n-1}\right) \\
& =a^{n}\left(a\left(1-b^{n+1}\right)^{n}\right) \\
& =a\left(a^{n}\left(1-b^{n+1}\right)^{n}\right) \\
& =a\left(\left(a\left(1-b^{n+1}\right)^{n}\right.\right. \\
\left(1-b^{n}\right)^{n-1} & \\
& \left.=a\left(a-a b^{n+1}\right)^{n}\right)
\end{aligned}
$$


terbukti bahwa $\left|A_{n}\right|=a\left(a-a b^{n}\right)^{n-1}$, dengan $n \geq 2$ berlaku untuk $\left|A_{n+1}\right|$.

\section{KESIMPULAN}

Hasil penelitian mengenai determinan matriks sirkulan dengan metode kondensasi Dodgson adalah sebagai berikut:

1. Hasil matriks kondensasi Dodgson pada matriks sirkulan berukuran $n$ akan memiliki $x$ entri berbeda sedemikian sehingga $x \leq n$,

2. Matriks kondensasi Dodgson pertama pada matriks sirkulan memenuhi bentuk matriks Toeplitz,

3. Kondensasi matriks pertama dari matriks sirkulan $A_{n}=\left(a_{0}, a_{1}, a_{2}, \cdots, a_{n-1}\right)$ sedemikian sehingga $a_{i}=a \cdot b^{i}$ dengan $a$ dan $b$ suatu konstanta, merupakan matriks bidiagonal bawah (bidiagonal lower matrix),

4. Determinan matriks sirkulan $A_{n}=\left(a_{0}, a_{1}, a_{2}, \cdots, a_{n-1}\right)$ sedemikian sehingga $a_{i}=a \cdot b^{i}$ dengan $a$ dan $b$ suatu konstanta adalah: $\left|A_{n}\right|=a\left(a-a b^{n}\right)^{n-1}$

\section{DAFTAR PUSTAKA}

[1]. Davis, P. J., Ciculant Matrix, Canada, 1979, John Wiley \& Sons.

[2]. Dodgson, C. L., Condensation of Determinants, Being a New and Brief Method for Computing their Arithmetical Values, Proceedings of the Royal Society of London, 15, 1867, 150155.

[3]. Fahlevi, M. R., Circulant Matrix and Field Axioms, Jurnal IImu Matematika dan Terapan, Barekeng, 14, 2020, 473-480.

[4]. Fitriyani, E., Helmi dan Ramadhani, E. W., Metode Alternatif Dalam Menentukan Determinan Matriks $n \times n$, Buletin Ilmiah Math. Stat. dan Terapannya, Bimaster, 07, 2018, 335342.

[5]. Goldberg, J. L., Matrix Theory with Aplication, USA, 1991, McGraw-Hill. Inc.

[6]. Gray, M. R., Toeplitz and Circulant Matrices: A Review, Foundations and Trends ${ }^{\circledR}$ in Communications and Information Theory, 02, 2006, 155-239.

[7]. Rahma, A. N., Safitri, E. dan Rahmawati, Determinan Matriks FLScirc $r$ Bentuk Khusus $n \times n$, $n \geq 3$ Menggunakan Metode Kondensasi Chio, Jurnal Sains Matematika dan Statistika, JSMS, 05, 2019, 23-29

[8]. Siregar, B., Invers Suatu Matriks Toeplitz Menggunakan Metode Adjoin, Jurnal IImiah Matematika, Saintia Matematika, 02, 2014, 85-94. 